Yeshiva University, Cardozo School of Law

LARC @ Cardozo Law

Articles

Faculty

1987

\title{
Literacy and the Language of the Early Common Law
}

Peter Goodrich

Benjamin N. Cardozo School of Law, goodrich@yu.edu

Follow this and additional works at: https://larc.cardozo.yu.edu/faculty-articles

Part of the Law Commons

\section{Recommended Citation}

Peter Goodrich, Literacy and the Language of the Early Common Law, 14 Journal of Law and Society 422 (1987).

Available at: https://larc.cardozo.yu.edu/faculty-articles/334

This Article is brought to you for free and open access by the Faculty at LARC @ Cardozo Law. It has been accepted for inclusion in Articles by an authorized administrator of LARC @ Cardozo Law. For more information, please contact larc@yu.edu. 


\title{
Literacy and the Languages of the Early Common Law
}

\author{
PETER GOODRICH*
}

Let us take up yet again this business of signs, for you have not understood, you have remained rationalists, semioticians, Westerners. ${ }^{1}$

The most famous of the libraries of antiquity was a collection of manuscripts brought together by the first of the Ptolemies in the third century B.C. in Alexandria. This "apogee of antique literary science"2 brought together under one roof the Museion-some 500,000 manuscripts and an academy of scholars dedicated to systematic philological research. In the form of a cult organisation under a priest of the Muses, the Alexandrian library produced a number of early forms of educational grammar and an elaborate classification of earlier literature according to schemata of authorship and genre. Interestingly, however, this ancient and exemplary monument to textual culture cannot be simply recorded as an instance of the growth of knowledge and of the ascendancy of the technologies of the written form. The Alexandrian Museion rapidly came to represent the dual aspect of writing as an institution both of progress and latterly of confinement. As the Alexandrian age proceeded, the Hellenistic culture which it hoarded and collated came increasingly to symbolise the accumulation and custody of relics - the establishment of a manuscript tradition alienated from living concerns and blighted by an élite literacy belonging to the external or 'other' world of writing. The massive accumulation of books led nowhere but to other books while the Ptolemaic linguistic consciousness symbolised nothing so much as the restriction of language to a single code, the now familiar dystopia in which the Babel of discourse was reduced to one canonic universal language in which the life of the book was exhausted in the realm of philology and bibliomania. It may well be that the history of the Museion is eventually to be remembered primarily for the idyll, the literary form in which book-weary Hellenistic scholars sang the praises of rustic life, of Sicily or Arcadia or the lesser islands where the poverty of existence was tempered only by the absence of writing and the oral tradition was as yet unwounded by the double-edged technology of literacy. ${ }^{3}$

Warnings as to the evil of writing are, of course, as familiar and as antiquated as literacy itself. Plato in the Phaedrus recalled the Egyptian myth

*Department of Law, University of Newcastle, Newcastle upon Tyne, England. 
of Theuth in which writing was admonished for "offering but the semblance of wisdom", and was stigmatised as no more than an 'external mark' which would instil forgetfulness in the soul, a "recipe not for memory, but for reminder". ${ }^{4}$ Lycurgus of Sparta, according to Plutarch, issued edicts banning writing because it threatened education and the virtues of citizenship. ${ }^{5}$ While the Spartans acknowledged writing as a strictly functional record of economic transactions, it was to be circumscribed by its wider context, one in which it did not disseminate so much as it destroyed the inner world of understanding in favour of mere obedience to law. Even within the supremely textual tradition of the Christian church the divine power of writing as scripture was constantly to be counterposed to the pentecostal 'gift of tongues' and the apostolic mission of taking the word to the people: 'the letter killeth, but the spirit giveth life' ${ }^{\prime 6}$ was through the ages the slogan of the sermo humilis and of the frequently heretical championing of the oral and vernacular against the established church and the Latin liturgy. To take a final example from the context of literary modernity, Foucault accorded Flaubert's The Temptation the dubious distinction of being "the first literary work to comprehend the greenish institutions where books are accumulated and the slow and incontrovertible vegetation of learning quietly proliferates". Flaubert is to the library what Manet is to the museum: "they erect their art within the archive ... every painting now belongs within the squared and massive surface of painting and all literary works are confined to the indefinite murmur of writing".? In sum, the paradoxical lament of the Alexandrian idyll, the nostalgic reinvocation of the pre-literate, the denial of the worth of literacy and of the dusty aura of manuscript and parchment, the sense of bookish confinement to the exclusion of a living discourse and a spoken truth are quite as common as the legalistic praise of writing as permanent mark and as selfassured and authentic record. "More fertile than the sleep of reason, the book perhaps engenders an infinite brood of monsters. Far from being a protection, it has liberated an obscure swarm of creatures and created a suspicious shadow through the mingling of images and knowledge."8

Scholars, of course, have a peculiar interest in reinstating the 'genuine' power of writing as rational discourse and in invoking a relation to the public sphere which would preserve the existing technology and forms of custody of administrative and legal knowledge. Where intellectuals decry the threat of illiteracy or bemoan the irrelevance of a particular form of literate knowledge and library learning there is always the possibility that the crisis is internal to the academy and that what is most immediately threatened is the status and survival of a particular clerical élite which lives, as much as anything else, upon the status of the book and the humanism it incorporates. ${ }^{9}$ There is a lengthy tradition, however, as well as a possible irony to contemporary concerns with the new technologies and the new media of communication and of record. Any form of literacy carries with it the dangerous double mark already observed in the advent of writing. It threatens the earlier tradition and custody of knowledge and information, it fractures the pre-existent unities of grammar and of semiosis as interpretation, it undermines the contemporary forms of 
reason and of rational discourse. In the moment of its birth the new technology of literacy unleashes not simply the possibility of more permanent or more efficient networks of information but equally the issues of access and control, the questions with which the doctrinal discourse of the disciplines is always at some level engaged. Who will determine which channels, data, and signs are forbidden? Who will know? Who will speak? What form will the new dialogue and rhetoric take, how will its masks be evaluated, and to what use will it be put? ${ }^{10}$

The questions which have consistently surrounded the development of new forms of literacy and new systems of signs are not to be understood as internal to the structure of signification nor as being reducible to issues of the accuracy and repetition of things represented. They are, rather, substantive and material aspects of the distribution of knowledge and the formation of archives and it is this material aspect of literacy which I will examine in the present essay in terms of the development and use of writing within the early years of the common law tradition. Varied in its languages and frequently distrustful in its recourse to writing, the common law tradition is something of a limiting instance in the history of legal texts. Prone as it has been to recollecting a myth of a spoken and accessible customary law and to berating the incursion of foreign scripts and alien written law, the mixed character of English law ${ }^{11}$ is fertile ground, both in doctrine and practice, for the analysis of conflicting literacies and competing groups of literati. Writing is never innocent nor singular:

... struggles for powers set various writings up against one another. Let us not shrug our shoulders too hastily, pretending to believe that war could thus be confined within the field of literati, in the library or the bookshop . . . the political question of literati, of intellectuals in the ideological apparatus, of the places and stockages of writing, of castephenomena, of 'priests' and the hoarding of codes, of archival matters - all this should concern us. ${ }^{12}$

The writings of the common law tradition, in contrast to the civilian doctrine of ratio scripta, at least have the benefit of never having been uniformly presented as an unequivocal unity. Their history and reception was consistently one of conflict between different institutions of confinement and of opposed schools of interpreters. The languages of record were from the beginning politically charged while the production, storage, and utility of legal documentation was the object of continuing dispute. There is, indeed, little evidence of legal writing being received as an unmitigated cultural good or as self-evidently rational, and it is such a context that it seems more immediately appropriate to raise the questions not only of who wrote, but also of where such writings were located, by whom were they protected, and to what public sphere did they speak.

\section{FORMS OF LITERACY}

The transition from orality to literacy has been praised and denigrated as a homogeneous phenomenon more often than the term literacy has been 
adequately defined. The tendency of contemporary studies is to overstate the uniform advance which literacy represents and to greatly overstress the unique features of the semitic phonetic alphabet as the facilitator of new forms of consciousness, of reason, and of science.$^{13}$ The alphabet becomes something of a key to a civilised mentality and the 'thunder-clap' of literacy brings on the storm of knowledge. A particular cultural form and use of literacy is thus reconstructed with all the enthusiasm that an Enlightenment concept of reason can bring to bear, to represent the phenomenon and function of literacy as such. It is precisely the tenuous and partial development of literacy in the early Middle Ages which can best disabuse a pre-eminently rationalist and ideologically saturated tale of unimpeded progress.

On reflection, it should indeed be obvious to the inhabitants of an era characterised by increasingly fragmented specialist knowledges and competing literate competencies, of new forms of literacy that are also often labelled illiteracy, that literacy is diverse in both its forms and social functions. For lawyers in particular, who, as will be examined later, lay claim to expertise in the translation of a language perculiarly of their own making, it should be obvious that the notion of literacy is polyvalent and clearly one of degree. Literacy connotes competence in or access to specific institutions and technologies, specific languages, and specific social roles. The competencies in question are too complex to be covered by a uniform concept of the ability to read and write, however such skills are defined. From the eleventh century to the fifteenth century - for my purposes the formative years of the common law tradition - reading and writing were distinctive skills and those who could in some measure read outnumbered by far those with access to the materials and implements of writing. For the period in question it was indeed reading and dictating that were coupled in the ars dictaminis (the art of composition/ dictation) rather than reading and writing, the latter being the function of the priestly scribe (scriptor). ${ }^{14}$

The precise meaning of literacy was also a much disputed issue during the medieval epoch itself. ${ }^{15}$ In the disputations of the inaptly named Dark Ages, differing forms of literacy struggled for dominance and, from St. Augustine to the scholastics, the term itself could refer to anything from profession of the Christian faith to knowledge of law, or from familiarity with Donatus's ars minor and maior - the rules of Latin grammar - to a knowledge of the classical authors and an ability to read and compose Latin verse. In a confusing array of usages, we thus find a leading Christian rhetorician of the sixth century, Pope Gregory the Great, denying the value of linguistic decorum and claiming to despise "the proper constructions and cases because I think it very unfitting that the words of the celestial oracle should be restricted by the rules of Donatus". ${ }^{16}$ Somewhat later the roles were reversed and the twelfth-century chronicler of St. Augustine's abbey at Canterbury referred to Hubert Walter, the chief justiciar and chancellor of England as well as founder of the royal archive, as laicus et illiteratus (as an illiterate member of the laity) and also as juris ignarus (a legal ignoramus). ${ }^{17}$ Somewhere in between the humanistic John of Salisbury, a contemporary and associate of Vacarius, observed stringently that: 
We find men, who profess all the arts, liberal and mechanical, but are ignorant of this very first one [grammar] without which it is futile to attempt to go on to the others. While other studies may also contribute to letters (litteratura), grammar alone has the unique privilege of making one lettered (litteratum). ${ }^{18}$

While admitting that the very distinction between literati and illiterati is frequently a misleading one in medieval usage, some semblance of substance to the distinction can be elicited by simple reference to the mode of production of writing, to the institutions, economy, and social role of script. First, I consider the restricted economy of writing. The new technology was based upon the Greek and Roman alphabetic script and during the Middle Ages used parchment and vellum rather than the classical papyrus as the form of written record. In that its techniques were difficult to learn and expensive to utilise both in terms of materials and in terms of skilled and arduous labour time, it was initially a highly restrictive and somewhat obscure enterprise. The physical act of writing was one in which "the whole body labours"19 and the scriptorium, which required expensive skills and materials, was sparingly used by the larger monasteries (where the scriptorium would generally be closed during the winter months) and later by clerics in the employ of the royal court and chancelleries. ${ }^{20}$ In terms of economic preliminaries, writing was the product of a very small élite of clerics who worked both in their own cause (that of transmitting the sacred writings) and also increasingly for a growing class of worldly patrons (the monarchy and aristocracy). In economic terms, medieval society of the eleventh century was literate in the sense that culturally essential knowledge was transmitted in writing - the Bible and its exegesis, statutory laws, charters, writs, and chronicles - but such literacy should not be equated with the ability to read and write. Literacy here means a combination of two circumstances:

(1) the need for access to the written tradition for the exercise of one's social function, and

(2) the use of available means of such access, be it one's own ability to read and write, or [more normally] another's. ${ }^{21}$

In institutional terms the sole heir to the schools and administrative literacy of the Roman empire was the monastery. The antique Church of the martyrs was succeeded by that of the monasteries, and from 500 A.D. onward the Benedictine orders took over in its entirety the task of transmission not simply of the truths of the faith and the history of the Church, but also of profane and sacred, legal and secular, learning. The monasteries became "the chief support - and from the eighth century onwards the only support - of writing and the book". ${ }^{22}$ While it is certainly true that the Church inherited a rhetorical tradition and a doctrine of the spoken word - a populist doctrine which stressed the oral art of preaching - it also came early to recognise the élite organisational power of writing and of the Latinate literacy upon which such power rested. With far-reaching consequences for European civilisation the Church monopolised the costly means and skills of literacy. By virtue of being the only institution capable of providing formal education, the Church regulated the number of scribes and restricted the manufacture and 
circulation of manuscripts according to its needs. The Church came to achieve an effective control over all social institutions, even monarchies, simply by taking priestly charge of the most powerful of the available means of transmitting the indispensable knowledge necessary for centralised organisation. That it was the Church that mobilised European society for the crusades simply reflected the fact that it was the literate Church alone among the European institutions that possessed the organisational and communicative capacity to take on such an enterprise. ${ }^{23}$

For several centuries writing was no more nor less than the discourse of the Church, and within that discourse were subsumed not only the subordinate administrative and legal documentations of the nascent bureaucracies but also the very concept of literacy itself. By the twelfth century the opposition between clericus and laicus (betwen the 'chosen' priestly élite and the 'crowd' or 'people') was synonymous with the opposition between literatus and illiteratus. Ecclesiastics and scholastics were by definition lettered while the laity - amongst whom the upper and commercial classes had generally, by the thirteenth century, some rudimentary reading skills - were by definition unlettered or illiterate. ${ }^{24}$ It remains to be noted that in its institutional context literacy connoted a specific Latinate form of literacy which the scholastics increasingly reduced to a set of technical rules, to authoritarian formal grammars of correct usage. In this form, Latin represented a dominant literacy, a learned language and alien writing adopted from the south for intrinsically political reasons whose dreary and legalistic authority was to be challenged consistently though in the main ineffectively by both oral and vernacular traditions. In terms of the social role of literacy, it may be concluded that the élite and exclusory status of Latin together with the consolidated administrative power of writing formed more of an obstacle to the development of social channels of communication than it acted as their facilitator. The phrase the 'Latin Middle Ages' constitutes a challenge rather than a statement. ${ }^{25}$

\section{ARCHIVE AND LIBRARY}

The definition of the technology of writing as being, like any other technology, governed by principles of economic and institutional role can serve as a useful starting-point for an examination of the emergence, storage, and uses of early records and books within the administrative and legal spheres of the AngloNorman state. The Latinate ecclesiastical context of this nascent textual tradition does not enable it to escape the conflict between oral and literate modes, nor does it immediately exclude the ambivalence and distrust of writing that accompanies all emergent literate traditions. The engrafted character of the manuscript tradition, the foreign form, and the alien language utilised by the priestly scribes, would have been sufficient on their own to ensure resistance at all levels of the social hierarchy. As it was, the tradition had also to face the additional burden of being itself internally divided both 
doctrinally and historically. The Church had inherited from the collapse of the Roman Empire a literacy that was geared to administrative and legal needs, a writing-system concerned with the profane requirements of organising and subjugating the imperial territories. Within this pre-eminently mundane form the Church had to accommodate the sacerdotal and symbolic needs of the living faith. For much of their early history the clerical records of both Church and State - the documentation of faith and law alike - represented the product of conflicting tendencies in which oral narrative forms and the metaphorical and magical properties of writing frequently overrode the claims of authentic record. The manuscript literature was as much the product of imagination and of the figurative aspirations of those seeking revelation as it was the literal representation of legal entitlements. ${ }^{26}$

The most basic unit of language, the sign, is derived etymologically from the Latin signum and refers to the pictorial marks used as standards by units of the Roman army. In an analogous fashion, the iconographic form of the sign is replicated in the metaphoric status of the written word and the symbolic character of the book (textus). The earliest literature known to the common law tradition is to be understood as metaphysical rather than practical, sacred and not profane in its import. For the Christian King Alfred it was "divine purpose, and not fate that rules" and his Laws were as much cosmological as substantively legal. They started with the Ten Commandments and moved to a restatement of the laws of Moses together with a summary of the Acts of the Apostles. Nor is there any substantial evidence of the Laws ever having had any practical significance. ${ }^{27}$ Even more strikingly, one of the first reported political decisions of William the Conqueror was that of emulating the emperors of antiquity and invoking the imperial dominium of civilian jurisprudence by bringing the conquered people under the rule of written law. With the continental jurisprudence came also the ecclesiastical Latin of the jus scriptum and the symbolism of the book. The most immediate and exemplary product of this imported literacy was no less a work than the Domesday Book, the very title of the work invoking Revelation, the book of judgment, of scripture, and of law - the last word both majestic and unalterable, magical and immune to the blandishments of time. What is important is that the Book is pre-eminently a symbol: its form was that of a liturgical text which irrevocably associated writing with royal power and its purpose was that of invoking the Justinian and Carolingian empire and imperium, the new start represented by the form of a code rather than a substantive body of decisions and rules. ${ }^{28}$ The available evidence indicates that Domesday Book was perceived as a public representation of power, a symbol of sovereignty, and not as a practical document. It was neither referred to in the plea rolls nor used in administration for the two centuries subsequent to its official promulgation.

The binding of legal writing to public statements of political power and feudal property right can also be evidenced by examination of the internal structure of the early forms of documentation. In a predominantly oral culture, writing was only one of many systems of record and title and it 
necessarily drew at least some of its terminology and methods from the competing rhetorical processes. While legal and administrative documentation grew during the twelfth and thirteenth centuries, their most important forms - the charters, chirographs, writs, memoranda, chronicles, and cartularies - were exceptions rather than norms of registration and record. It is not simply that they were élite and restricted forms of public statement but also that they were cross-cut by earlier traditions of symbolisation and reporting. For obvious reasons they were neither the subject of any rigorous procedures of authentication or accuracy nor were they the object of any systematic concept of the exhaustive or originary quality of written proof. As late as the thirteenth century, a legal record (recordationem) was still a form of oral witness, a deed (factum) was a physical act and not a conveyance, while that fond obscurantism of property lawyers, seisin, meant physical possession and no more technical legal form of title. ${ }^{29}$

In a period when a book (textus) simply meant an interweaving of disparate elements - a compilation of diverse manuscripts or fragments brought together within the sacred covers of the book - it takes little imagination to perceive that writing would for long remain as much a mystical as a mundane exercise. Writing has a reciprocal relationship to rhetorical culture: the monastic histories and registers were quite literally fictions, panegyric narratives which incidentally related founding donations of land only when written testimony - black paint on sheep skin (wethers) - became an occasional aid in warding off royal encroachment on monastic title. ${ }^{30}$ Similarly the writs, charters, plea rolls, and Year Books were haphazard collections of legal materials. The former were frequently forged as necessity occasioned, while the latter were subject to no systematic tabulation or indexing, nor were they records so much as compendia of pleas and arguments, the documentation of rhetorical exercises and seldom of judgment. $^{31}$ Where writing was used as proof it had its adjuncts and complements in symbolic objects: swords, daggers, and other treasured relics as well as in the pervasive rhetorical art of memoria. Access to the magical properties of legal title and remedy was not in general a literary exercise. When in 1301 King Edward endeavoured to prove title to the kingdom of Scotland his arguments were based upon narrative and myth and not at first upon any written proof of jurisdiction. Only when the iconic and oral signs had failed in their task did Edward resort to the archive, to the "chronicles and registers" which in their turn proved insufficiently persuasive. ${ }^{32}$ Even more graphically, the quo warranto (by what warrant) proceedings of King Edward's reign had to be abandoned because written title to land was too exceptional and too untrustworthy to form the basis of legal claims. ${ }^{33}$

The context of writing was rhetoric, a discipline which was well described by C. S. Lewis as the "greatest barrier between us and our ancestors". ${ }^{34}$ Oral skills, memory, and testimony, as well as the various iconographic and unwritten signs or figurations formed the central elements of legal procedure in the twelfth and thirteenth centuries. As is well known, the antecedents of the legal profession were oral pleaders, narrators (conteurs) who literally told a 
tale and argued a cause, frequently relying for their interpretation of the law upon the rhetorically skilled knights, the buzones judiciorum referred to by Bracton. ${ }^{33}$ Where documentation was referred to, the manuscripts were ornate and embellished, their text was interwoven with visual signs of classification, with systems of symbols and interlinear glosses. And their library was the treasure chest, the sanctuary, or the chapel. They were "holy mysteries', tenacious letters that far from publicising their contents were, according to Fitzneal's Dialogus, stored in sacred hiding places - sacramentorum latibula. The term archive (archiva) itself refers to a hiding place, and both the book and its repositories were sacred and not secular. Statutory laws and charters as well as chronicles and registers were dedicated and addressed not to their readers but to God and to eternity. The book itself was a depository for disparate manuscripts and its covers were a protection and sacralisation of its contents - the book would be placed upon the altar before being stored in a sacred place under the guardianship of heaven for the benefit of posterity rather than for the immediate purposes of administration. The document was almost immediately a relic surrounded by stone and anathemas and even legal records were scattered between different religious houses before coming to be kept in the chapter house of Westminster abbey. There is evidence that they were later moved to the New Temple in London and later still in the fourteenth century to the White Chapel in the Tower. ${ }^{36}$

\section{LANGUAGES OF THE LAW}

The powers attributed to the alphabet, to the "signs that bring the speech of one absent to our ears without voice", 37 as well as to the books and to the mysteries of the scriptorium, find ample expression in the languages of medieval culture. Preceding and co-existent with the legal uses of writing there is a metaphorics of writing, of Hermes and the Muses, which the Christian tradition supplements with books which decide the fate of the soul in eternity (Revelations 20.12f), with "heavens [which] shall be rolled together as a scroll" (Isiah 34.4) and with tables of law "written with the finger of God" (Exodus 31.18). For medieval jurisprudence God was the source of all law and tacitly if not explicitly the author of all books. Ultimately the laws of the kingdom were derived from God's commandments, and for John of Salisbury in the Policraticus the lineage of positive law was expressly one which moved from the imago dei to the rex to lex animata. ${ }^{38}$ It should thus occasion little surprise that the language of the law came initially from the Church.

\section{Law Latin}

While William the Conqueror is accorded the role of having introduced juri scripto legibusque into the oral and vernacular tradition of properly English law, the Latinate literacy is in fact much older. Coke's Reports provide uncertain evidence of the 'learnedly archaic' language of Celtic laws, "they 
used to do it in the Greek tongue, so that the discipline might not be made common among the vulgar", ${ }^{39}$ but the first substantial evidence of the languages of legal literacy dates from the later years of the Roman occupation when the Christian Church made its first steps into Britain, and by the late seventh century England was officially Christian. With the Church, of course, came renewed ties with the continent, a knowledge of writing, a reintroduction of Latin, and a vocabulary that was to remain a significant part of the later law. ${ }^{40}$

Latin received a major further impetus from the Norman invasion and rapidly became the dominant written language of English law, of the early statutes, charters, and writs. Although William separated Church courts from secular courts, the influence of the Church was pervasive in both. In keeping with the history of medieval Latinate literacy in general, it was the Church that both trained and regulateo scribal classes used in the chancellery and the royal courts, while it was also from the ecclesiastical class that the first chancellors, royal judges, and legal drafters were drawn. The royal law that became the early and curiously-named 'common' law was devised not by the express will of the people (voluntas populi) but by clerics employed by the crown and trained in canon and Roman law. ${ }^{41}$ Owing more to the Latin tradition and the feudal role of the aristocracy than to vernacular traditions, the rapidly formalised writing of the early common law soon sedimented in ritual patterns, in verbose Latin statutes, Latin plea rolls, writs, and formularies. Although recent scholarship now dates the first English law school at Oxford from the 1190 s and doubts that the glossatorially trained Vacarius played any greater role in its formation than that of providing the first textbook (the Liber Pauperum), there is no doubting that for the purposes of administrative and legal writing it was the civilian tradition imported from Bologna, Montpellier, and Paris that formed the essential model of legal study. ${ }^{42}$

Those aristocrats and aspirant clerics who wished to study law could only do so by attending the continental schools at great expense and by learning the methods and techniques of Justinian's law. If the first major treatise on English law, attributed to Glanvill though perhaps written by Hubert Walter, constituted a "revolution in legal science", ${ }^{43}$ it did so by systematically and expressly applying a civilian methodology and language to the writs and other forms of the common law in the hope of proving that the English law, though unwritten, was as valid as the lex scripta. ${ }^{44}$ The Latinate influence of Vacarius and of Glanvill lay at the heart of the early language and structure of the common law, and the social and linguistic significance of this early influence can usefully be examined in two forms: first and briefly, in terms of the general political role of Latin; and second, in terms of the distinctive features of the peculiarly English form of law Latin.

The Latin inherited from Rome by the nascent medieval European states was not classical Latin but rather the predominantly textual language of the empire. It was only with the growth of the empire that the rhetorical Latin developed during the later Republic became subject both to the centripetal pressures of the imperial bureaucracy and to the equally unifying rules of 
standard grammars and norms of correct written usage. Following close on the heels of the legions came the grammarians who would translate the military subjection of the imperial territories into the requirements of a dominant discourse: the regularity and obedience demanded by fixed texts and invariant rules of spelling and syntax. ${ }^{45}$ In a famous anecdote from Suetonius, the emperor Augustus, who.was himself reported to be eccentric in his spelling and grammatical usage, ordered the removal of a consular governor for being rudis et indoctus (backivard and ignorant) simply because he had written ixi for ipsi. ${ }^{46}$ Grammar and strict codes of correct usage worked both to instil a particular ideology but also ensured the Alexandrian decline of the written language once formalised usage became historically divorced from vernacular practice. ${ }^{47}$ Latin became a learned language in both senses of the word, a language of administration and of power at the pinnacle of the social hierarchy of discourses. It was pre-eminently a social language, a language conferring status which Bakhtin has dubbed a 'unitary' language representing the "victory of one reigning language (dialect) over others", a usage which serves to direct attention "away from language plurality to a simple proto-language", a Ptolemaic or absolutist linguistic consiciousness "from whose point of view other languages are perceived as in no way its equal". 48

Turning to the particularity of the common law tradition, it remains for me to specify the development of a unitary written discourse within the AngloNorman realm up to the mid-thirteenth century when law French in some measure replaced law Latin. ${ }^{49}$ Law Latin, while it certainly adopted the unitary characteristics of the general Latinate culture and equally made use of the mystical symbolics of writing and the clerical culture of the book, developed certain idiosyncracies and usages of its own. Indebitatus assumpsit (being indebted he undertook), for example, would in classical Latin mean that he was not in debt, the prefix in meaning not. Other usages were coined from Latin; fieri facias (cause to be made), habeas corpus (have the body), mandamus (we command), subpoena (under a penalty) being early and legally obvious examples. ${ }^{50}$ However, the development of a Latin that was specialist even to the general Latin culture served only to re-emphasise the restricted guild character of early legal writing. Coke in James Osborne's Case ${ }^{51}$ referred to "words significant, and known to the sages of the law, but not allowed by grammarians". Coke's 'false and incongruous Latin' was explained by Blackstone as being in reality "a mere technical language, calculated [nonetheless] for eternal duration, and easy to be apprehended both in present and future times; and on those accounts best suited to preserve those memorials which are intended for perpetual rules of action". 52

The unitary role of law Latin was not, however, only a question of the grammatical structure or internal cohesion of the legal usages so much as it was a party to the general ideological thrust of the writing system to which it belonged. Latin literacy was always to a greater or lesser degree a minority skill which protected itself behind a hostile condescension towards the oral and the vernacular. Where Pliny the Younger referred to the ragged and filthy 
crowd (sordidi pullatique ${ }^{53}$ ), Walter of Chatillon - a curricula author of the twelfth century - was less restrained in describing the unlettered as animae brutae. ${ }^{54}$ Latin alone had the 'dignity of eloquence' in the twelfth and thirteenth centuries and the clerical justice Walter Map expressed a common view in dismissing the 'vulgar' tongues (English and French alike) as being fit only for the "trifling of mummers in vulgar rhymes". Slightly later the Oxford scholar Father Roger Bacon was cosmological in his scope, stating that:

... from the beginning of the world the common people (vulgus) were separated from the knowledge (sensus) of the saints, the philosophers, and all other wise people, and all wise men despised the ways of the common people. ${ }^{5 s}$

For the twelfth-century abbot Philip of Havengt, literacy of itself raised an individual well above other people, and even Dante referred to moderni bruti, although in a somewhat different context. ${ }^{56}$

\section{Law French}

Written Latin remained the sole language of legal record for the two centuries following the Norman Conquest. It was the exclusive language of statutes up until the mid-thirteenth century and even in the late thirteenth century it still predominated. Latin was the language of the plea rolls, of the register of writs (Registrum Brevium), and of the court records up until the seventeenth century. When written pleadings were introduced in the early fourteenth century they were in Latin and also remained so until the seventeenth century. More interestingly and importantly, the Latin influence lived on in the new vernacular literacies, both in elements of their vocabulary and, more importantly, in their formulation of grammatical rules.

Latin was both an obstacle and an aid in the development of alternative literacies. The vernacular languages were initially disparaged throughout Europe, and the administrative centres and languages remained resolutely Latinate in emulation of the western Roman empire to which they saw themselves as successors. Denied access to the status of literacy, the unwritten vernaculars developed haphazardly as oral dialects varying from region to region and from context to context. The local character and unstandardised usages of these linguistic communities did not, however, prevent their being identified with the political aspirations of their community. That Latin lived on so long as the written language of the Anglo-Norman administration can plausibly be interpreted as a result of the political competition between middle English and French as alternative literary languages. For some considerable time, the stigmatisation of the vernacular assigned French and English to the peripheral role of languages of entertainment and of the written romances (histories) - works performed for the amusement of very small and élite aristocratic groups. ${ }^{57}$

When French came to compete with Latin as the language of administration in the thirteenth century, it was Latin that unsurprisingly formed its model of systematisation and it was, somewhat more paradoxically, from the centres of 
the learned language that the impetus came. It was the scholastics who first applied the Latinate rules of correct usage and grammar to the vernacular languages and worked to systematise their styles according to classical techniques. The vernaculars required 'Latin tutelage' and this they received only when sufficient political will and cultural authority had been invested in them. The political backing of French was the product of the middle years of the thirteenth century, the period which in all probability witnessed the first Year Books as well as the first French language statutes, charters, textbooks, wills, and other memoranda. It is of the law French of the Year Books that the incomparable stylist Maitland baldly and surprisingly stated "that precise ideas are here expressed in precise terms, everyone of which is French: the geometer or the chemist could hardly wish for terms that are more exact or less liable to have their edges worn away by the vulgar"..$^{88}$ English lawyers, for Maitland, had enjoyed the "inestimable advantage" of being able to forge their very own technical language, a language impervious to foreign influence by virtue of its very technicality.

Maitland's views may well have given expression to the aspirations of the early systematisers of law French, though it is more likely that the justificatory rhetoric enclosing the new written language hid the economic and political utility of the language to an as yet uncertain profession and its need for mysteries around which to form an exclusive and expensive medieval cult. What is much less arguable in the face of the reports themselves is the pious belief that the new language was either precise or unchanging. At one level Maitland simply gave expression to a long-standing legal doctrinal dogma, one which was equally well elaborated in the earlier institutional writings of Coke and Blackstone. ${ }^{59}$ In the Commentary on Littleton the argument put forward in favour of law French was precisely analogous. Law French was learned French and not a spoken dialect, it could not be either "pure or well pronounced" and similarly one would find in it "a whole army of words, which cannot defend themselves in bello grammaticali, in the grammatical war, and yet are most significant, compendious, and effectual to express the true sense of the matter". ${ }^{60}$ The ancient terms drawn from legal French were to be considered a vocabula artis assigning precise meanings to intricate legal concepts.

It may be noted first that to its contemporaries the new verbal alchemy was somewhat less than attractive and that as early as the mid-fourteenth century the Statute of Pleadings 1364 gave written form to the voluble outcry of the majority of English-speaking communities. Ironically, the Statute of Pleadings was drafted in French and the relevant clause, a sentence 384 words in length, allowed that the court records were to remain in Latin. The central issue was addressed in clause 15(2) where it stated that:

... reasonably the said laws and customs the rather shall be perceived and known, and
better understood in the tongue used in the said realm, and by so much every man of the
said realm may the better keep, save, and defend his heritage and possessions...

On the other hand, subsections (5) and (6) allowed that "ancient terms and forms" were to be "holden and kept as they be and have been before this 
time". In short, the Statute of Pleadings was significant as a documentary record of the degree of resistance to the administrative use of law French, but as substantive law it was equivocal, inconsistent, and ineffective. Later attempts to legislate in favour of the vernacular and against the "unknown tongue" of the lawyer, the nomenclature which Bentham vividly depicted as "devised in a barbarous age, by a mixture of stupidity, ignorance, error and lawyer-craft", were equally ineffective and short-lived. ${ }^{62}$ In $1650 \mathrm{An} \mathrm{Act}$ for turning the Books of the Law, and all Process and Proceedings in the Court of Justice, into English lasted only so long as the Commonwealth and was repealed with the Restoration of 1660 , while new legislation in 1731 had little substantive effect upon the literate practices of either the courts or the legal profession. ${ }^{63}$

The context of law French as a written language was that of Latin, a tradition of the fixed text in which the standardisation of meanings within a sclerotic learned language had to be counterposed to the mysterious symbolics and custody of iconic and sacral manuscripts. Divorced from the classical rhetorical tradition with its emphasis on practice as opposed to the schematic logic of medieval dialectic, Latin literacy had become a doctrine of canonic meanings and of rituals of sanctity and obedience. While law French never achieved either the internationalism or the coherence of its Latin model, it certainly made use of the vitriolic ideology of the unitary language. In practice law French was characterised by a mixing of archaic terms with coined usages. It was polyglot in its recourse both to Latin and to middle English legal terms and its style reflected all the pomposity and prolixity of a register which happily used synonyms drawn from three eras and communities of language where one could have served much better. ${ }^{64}$ Its grammar and specialism were less the result of technical precision than the outcome of specific institutional factors. The changing nature of property ownership required the rapid proliferation of terminologies. The severity of the law encouraged fervent particularism in a system which boasted near on a hundred capital felonies at the end of the seventeenth century inclusive of being an 'Egyptian' or a Catholic priest, or for 'conjuring wicked spirits'. 65 The profession itself was poorly trained, little regulated, and, most indicatively of all, its scribes were paid on the basis of the length of the documents they produced. ${ }^{60}$ The atmosphere of the profession was one of dialectical and verbal sophistry. Its intellectual pretensions were played out in the specious "wittes of logitians" 67 and its rhetorical aspirations - "a shadow of the ancient rhetoricke" 68 led little further than the aristocratic parlour-game disputations of the Inns of Court. ${ }^{69}$ Even the legalistic witch-burning Mathew Hale, appointed I ord Chief Justice in 1671, spoke of the written law "as the rolling of a snowball, it increaseth in bulk in every age, till it become utterly unmanageable every age did retain somewhat of what was past, and added somewhat of its own. And this produceth mistakes. ... It must necessarily cause ignorance in the professors and profession itself." 70

To the multilingual character of the law books must finally be added the explicitly exclusory stance of legal doctrine toward all other linguistic 
communities and usages. Just as Latin had preserved its unitary status as a discourse by scorning the vernacular, law French would brook no challenges from non-legal dialects. Armed with little more than an amorphous history of lexical invention and a ready willingness for linguistic pastiche, the old arguments of the classicists were rolled out for the benefit of the new and more diverse literary form. For the Lord Chancellor Francis Bacon the closure of legal discourse was necessitated by "these modern languages [which will], at one time or other, play the bankrupt with the books". ${ }^{71}$ Coke was more direct and simply observed that:

\begin{abstract}
... it was not thought fit nor convenient, to publish either [the Reports] or the statutes enacted in those days in the common tongue, lest the unlearned by bare reading without right understanding might suck out errors, and trusting to their conceit, might endamage themselves, and sometimes fall into destruction. ${ }^{72}$
\end{abstract}

While the sixteenth and seventeenth centuries saw increasing protest at the arcane usages of law French, even the reforming statutes dared not remove the offending vocabularies, and apologists such as Roger North in the eighteenth century continued to argue the curious view that "the law is scarce expressible properly in English". To attempt an English rendition of the law was 'uncouth', the work was that of the wrangler and not that of the authentic lawyer in the genuine language of the law. ${ }^{73}$

\title{
THE PUBLIC SPHERE OF LAW
}

The indications already given as to the material character of the technology of writing, its forms of custody, and its variable languages all suggest that the public spheres of legal writing were limited and élitist. More interestingly and controversially, the sacral and iconic aspects of the development of the literate culture also suggest that its public sphere was more complex and many-tiered than the doctrinal supposition of a unitary language has generally allowed. Both within and without the profession, the development and languages of 'the books' of the law formed a dialogic history accompanied by numerous polemics, by competing discourses, and by the conflict between different institutional and social conceptions of the status and role of the written sign. In the early epochs of common law discourse the ecclesiastics, both canonist and civilian, the monarchy, the loose groupings of narrators, notaries, and treatise writers, as well as the judiciary themselves all sought to some degree to influence both the discourse and the language of the nascent legal order. The notion of the sign as simple representation of a 'thing' signified, as a graphematic substitute for the spoken message, or as the code allowing retrieval of an externally existent 'information' foretold the distant spectres of a future and desolate philology ending contemporarily in linguistics and the positivist variants of semiotics. ${ }^{74}$ Before it became representational, the written sign bore with it a more complex array of awe and of play, of an exegesis but also a hedonism of discursive signification more closely allied to allegory and mask than to scholastic certainties or the grammarian's truth. ${ }^{75}$ 
The very notion of a public sphere is republican and not theocratic. It properly belongs to the short-lived classical epochs of ancient rhetoric and is by definition resistant to the discursive closures of the scholastic dialectic and its imperially-derived literate forms. While there is no direct parallel between the classical institutions and audiences and the medieval reception of the ancient texts, a brief analysis of the concept itself necessitates its placement in its earlier discursive home. While the concept of a public sphere, of the agora and other assemblies, was intrinsic to the development of the epic and forensic oratory of Homeric and classical Greece, the tradition in question was primarily an oral one. Certainly Greece was literate and the Athenian laws had been codified as early as the sixth century B.C., but the pre-eminently oral tradition of argumentation that accompanied those laws rendered them largely irrelevant to the substantive practices of the public sphere:

An Athenian could not even imagine relying on official registration procedures, written documents and the interpretation by legal experts of an unambiguous body of written rules to define his status and secure his rights. ${ }^{76}$

The relevant model of a literate public sphere is rather to be located in the late classical and early imperial eras of the Roman Republic. Within the protean concept of res publica are to be found not simply the oral disputations of the senate as law-makers or the erudite casuistry of the élite juristic schools, but also the public declaration and promulgation of written law, the development of plebiscites and somewhat later the growth of the bibliopola (book publishers) and the accompanying creation of specific public spaces for the dissemination of literary works, the triclinia and auditoria of the great houses as well as the public buildings dating from the reign of Hadrian." As well as the public reading of laws and other literary works, the evidence of the literature itself demonstrates the broad constitution and scope of the specifically literate public sphere. It was neither exclusively Roman nor simply patrician. Rather, it was the product of the empire, of the spread of elementary schooling in grammar and rhetoric. Having but one of its centres, though a significant one, in the legal sphere of the jury trial and forensic address, the literate public grew with the administrative bureaucracy of Rome's military possessions. It was entirely in keeping with the cosmopolitan character of this educated public that Pliny related how Tacitus at the Roman games told his neighbour, in all probability a nobleman from Gaul, that "You know me from my writings", to which the knight reponded "Are you Tacitus or Pliny?"18

The most relevant feature of the classical public sphere was its essential linkage to political decision-making. Forming the opposite extreme of the Alexandrian philology, the life of the literary community as in any way an active institution was everywhere tied to its involvement in the formation of both social and military policy. Without suggesting that this in any sense formed the kind of ideal discourse situation invoked by contemporary humanists, ${ }^{79}$ it may still usefully be asserted that the community to which Cicero, Atticus, Tacitus or Pliny belonged was marked by a genuinely Hellenistic form of political dialogue and persona, "the great game of public 
life, the struggle for power, in which the personality unfolds before the eyes of all" and human life was staked immoderately upon the political fate of the community. ${ }^{80}$ Tacitus in the Dialogus provided the most eloquent testimony to the death of an institution and not simply an art. The public sphere had been built around forms of political and legal practice; the courts, the hustings, the plebiscites, and the senate house provided the occasions of a broad practice which needed both power and community to sustain it, "for the true basis of eloquence is not theoretical knowledge only, but in a far greater degree natural capacity and practical exercise". ${ }^{81}$ In the era of the empire, Tacitus perceived the growing degeneracy of schools which had no extant link with practice, no topics nor audience ${ }^{82}$ by which to fuel the 'flame of eloquence'. Most tellingly, he attributed the decline to the changing form of government: "What is the use of one harangue after another on public platforms, when it is not the ignorant multitude that decides the political issue, but a monarch who is the incarnation of wisdom?"83 With the contraction of the political institutions and processes, satire, theatre, literature, and poetry also waned. Pliny referred to a situation "quite different from that of Cicero, to whose example you refer me.... I have no need to tell you what narrow limits are imposed on me."84 Those limits long outlived the fall of the western Roman empire and when it comes to delineating the public sphere of Anglo-Norman legal processes, their definition can only be attempted in the largely negative terms inherited from the declining years of a moribund tradition. In so far as many of the relevant considerations have already been outlined, I shall provide a schematic elaboration around three key issues: those of the forms of written address, their institutional audiences, and finally, the role of written communication in the formation of legal discourse.

The many-tiered significance of the written sign - its simple representation, evocations, and invocations - may be traced initially to the theocratic mode of its internal address. It is not only that the early codes and writings were religious in their origin and sacral in their content and custody, but they were also explicitly addressed and presented to the divine auditor (public). The written law did not invoke a secular enforcement, but rather invoked and addressed God as both cause and support. Legal offers were offerings to God, title was the inscription on the cross, and for King Athelstan, in a charter of 934, those who ignored the disposition granted "shall be the companions of Judas, the betrayer of Christ, enduring punishment for all time in the torment of hell". In another tenth-century deed, the explicit support of delivery and possession invoked by the written law was not the 'external mark' of the document itself but rather the incorporeal threat of excommunication from the living Christ in which infractors "shall be cut off and hurled into the abyss of hell for ever and without end". ${ }^{85}$ This hieroglyphic writing enfolded the secular in the invisible scripture of the 'other world'. It brought with it the need for the authorities (auctoritates) and custodianship of the priesthood. Even Magna Carta in 1215 conferred 'by the grace of God' a concession from the sovereign, the human representative of the divine will: "we have granted to God, and by this our present charter have confirmed for us and our heirs for 
ever that the English church shall be free and shall have her rights and liberties, whole and inviolable". ${ }^{86}$ The validity of the document was not representational so much as it was a medium of divine inscription and a symbol, an allegory of the hidden word. It spoke the language of the sacred and not merely the profane, its protection was the wrath of heaven and it was to be treasured not as an administrative utility but as a benefit or concession, a magical relic belonging in a loose sense to the early museum, the sepulchral home in which the right of might was mysteriously transformed, in the face of history, into legal title.

The institutional bearers of the early manuscripts needed the political backing of church and monarch to preserve their hostage properties precisely because the Anglo-Saxon tradition was resistant to the new technology of writing and its foreign exponents and languages. The early writing was used not to record - in our barren contemporary sense of a correspondence between signifier and signified - but rather to establish in a negative and monologic fashion a public statement of sovereign power. It thus seems plausible to interpret the narrative vagaries of the early documentation and the curious ambivalence of their usage both as evidence of the absence of an indigenous public sphere and also as a record of resistance to the claims of conflicting language communities. While there was a marked growth in the use of documents for purposes of economic transaction and property title in the thirteenth century, the use of writing for procedures of registration and identification did not escape the ambivalent mark of the iconic and symbolic politics of writing.

Outside of the Church and the monastic schools, there was no public sphere or literate audience that might participate in a more general culture of writing or literate dialogue, but simply an oral and vernacular tradition which was largely hostile to the imposition of a Latinate tradition of manuscripts. Writing was by its nature and language learned, and its only audience must have shared its concerns and topics which were correspondingly liturgical and administrative. ${ }^{87}$ What evidence is available suggests that the first literate élite in twelfth-century England consisted almost exclusively of the high AngloNorman nobility; that it was dependent upon clerics under the patronage of the aristocracy; and that it nowhere approached the formation of a public sphere that could be termed a reading audience. ${ }^{88}$ What scholarly community there was came to England from the continent, the first university schools did not emerge until the end of the twelfth century, and what participation there was in intellectual life was rare, the scholars living in schools dispersed across Europe and only irregularly communicating with one another. ${ }^{89}$ The nonscholarly community was even more restricted and concerned with narrative history, legend, and myth best exemplified in Geoffrey of Monmouth's Historia regum Britanniae (1130), a successful and fabulist account of early English historical legends which was sufficiently imaginative to offend neither of the dominant national groups.

The administrative use of writing must necessarily have had a quality not of dialogue but of statements which were neither readily intelligible nor even 
accessible. The economy of the manuscript tradition restricted the circulation of documents to the monasteries and the administration, there were no other secular libraries or archives outside of a very few and small collections in the treasure chests of the nobility. Where documents did appear in the public domain it is, therefore, unsurprising that they appeared as foreign and instrusive to their subjects and were prone rather to impress or mystify than to inform. The ill-fated Thomas More writing in the early sixteenth century was forced in his Utopia to the view that lawyers were "a sort of people whose profession it is to disguise matters" and moderately observed that it was an "unreasonable thing to oblige men to obey a body of laws that are both of such bulk, and so dark as not to be read and understood by every one of the subjects". ${ }^{90}$ Even earlier, the judiciary of the twelfth and thirteenth centuries had no great faith in written records. Constantly forged, they lacked any ready means of authentification in a culture of juries and oral testimony, the quo warranto proceedings collapsed because written evidence was too haphazard and recent to be acceptable as proof, while when in 1279 Roger of Seaton retired from the Bench, he stated that his plea rolls, now deposited in the New Temple, could not be vouched for "because one thing is done and something else-more or less - is written in the rolls by the clerks, who are always failing to understand the litigants and disputants correctly".91 The monumental quality of documentation inscribed and preserved the records more for posterity than for any existent audience or practice.

There is, finally, the danger of writing both as a literal threat, a technology which purports by alien means to prove alternative titles to feudal status and property, but also a history of usages more fecund and varied than any simple utilitarian concept will allow. To the Romans of the pre-classical era, litteratus meant to be branded with a letter of the alphabet, to be marked as a slave. Writing was a means of power and that power later took novel forms in the code and in written law. The history of those different modes of writing system registered both power and resistance to the 'imaginings' summoned by manuscript and book. The unitary character of legal discourse derived from a culturally specific form of written power, a Latinate literacy and grammar which was neither incontestable in its form nor singular in its practices. Writing may well record but it may also be concluded that its history is redolent of other promises and dangers. There is the danger specifically of a form of literacy which controls and censors by a logic of exclusion - a literacy of closure which acts not so much as a reminder but as a means of forgetting. It is salutary to recall that writing may also function in the institution as a form of delirium in which lawyers write so as not to speak, in which they intone ritual formulae so as to avoid thinking and, in sum, exhaust their knowledge of writing in the subtle and subdued casuistry of an unwarranted bibliomania locked in the sanctuary of the latter-day archive. 


\section{NOTES AND REFERENCES}

2

Phaedrus (1952) pp. 274-5.

3 Plutarch's Lives (Loeb Classical Library ed. 1914) pp. 240-2.

Corinthians II.iii.3.

7 M. Foucault, Language, Counter-Memory, Practice (1977) pp. 92-3; see also, D. Crimp, "On the Museum's Ruins" in H. Foster (ed.), Postmodern Culture (1985).

8 Foucault, op. cit., n. 7, p. 94

J. Derrida, Of Grammatology (1976) pp. 6-15, 131-5, and Writing and Difference (1978) chap. 3.

J.-F. Lyotard, The Postmodern Condition (1984) pp. 5-6, 14-5, 80-1; P. Bourdieu, Homo Academicus (1981); R. Debray, Le Scribe (1985).

See, for example, John Warr in the mid-seventeenth century: ". . . the unknownness of the law, being in a strange tongue; whereas when the law was in a known tongue, as before the Conquest, a man might be his own advocate." (6 Harleian Miscellany (new ed. 1810) pp. 222-3).

2 J. Derrida, "Scribble (writing-power)" (1979) Yale French Studies p. 117 at p. 118.

13 For example, J. Goody and I. Watt, "The Consequences of Literacy" in J. Goody (ed.), Literacy in Traditional Societies (1968); J. Goody, The Domestication of the Savage Mind (1977); C. Levi-Strauss, The Savage Mind (1966); W. Ong, Orality and Literacy (1982). More generally, see: A. Havelock, Preface to Plato (1963); I. J. Gelb, A Study of Writing (1963); D. Diringer, Writing (1962); H. J. Graff, The Legacies of Literacy (1987).

Particularly useful are: E. Auerbach, Literary Language and its Public in Late Antiquity and the Middle Ages (1965); M. T. Clanchy, From Memory to Written Record (1979); F. H. Bauml, "Varieties and Consequences of Medieval Literacy and Illiteracy" (1980) 55 Speculum pp. 237-65; J. J. Murphy (ed.), Medieval Eloquence (1978).

See E. R. Curtius, op. cit., n. 2, chap. 3; E. Auerbach, op. cit., n. 14, pp. 102-5, 207-16; M. T. Clanchy, op. cit., n. 14, pp. 177-91; R. Pattison, op. cit., n. 3, pp. 75-85.

See H. J. Chaytor, From Script to Print (1945) p. 32.

Discussed in Clanchy, op. cit., n. 14, p. 180.

John of Salisbury, Metalogicon (1955) 1.21, 1.24.

Orderic Vitalis, cited in Clanchy, op. cit., n. 14, p. 90; see also W. Ong, op. cit., n. 13, pp. 94-5. More generally, see J. Goody, op. cit., n. 13; R. Pattison, op. cit., n. 3.

V. H. Galbraith, "The Literacy of the Medieval English Kings" (1935) 21 Proceedings of the British Academy pp. 201-38.

F. H. Bauml, op. cit., n. 14, pp. 243-4.

E. R. Curtius, op. cit., n. 2, pp. 311-5; H. J. Berman, Law and Revolution (1983) pp. 62-8; Brooke and Luscombe (eds.), Church and Government in the Middle Ages (1976) chap. 1.

R. Pattison, op. cit., n. 3, pp. 79-83; E. Auerbach, op. cit., n. 14.

See particularly M. T. Clanchy, op. cit., n. 14, pp. 177-9; Auerbach, op. cit., n. 14, pp. 253-5. See M. Richter, "A Socio-linguistic Approach to the Latin Middle Ages" in D. Baker (ed.), Materials, Sources and Methods of Ecclesiastical History (1975).

Generally, see W. Ong, op. cit., n. 13, chap. 4, and The Interfaces of the Word (1977); R. Crosby, "Oral Delivery in the Middle Ages" (1936) 11 Speculum pp. 88-110; M. T. Clanchy, op. cit., n. 14, pp. 202-30.

7 W. Ullman, Law and Politics in the Middle Ages (1975) chap. 6; H. J. Berman, op. cit., n. 22, chap. 1.

On Domesday Book, see Clanchy, op. cit., n. 14, chap. 1; R. W. Southern, "The Sense of the

Past" (1973) 23 Transactions of the Royal Historical Society p. 247; C. P. Wormald, "The Uses of Literacy in Anglo-Saxon England" (1977) 25 Transactions of the Royal Historical Society p. 113; J. Campbell, "Observations'on the English Government from the Tenth 
Century to the Twelfth Century" (1975) 25 Transactions of the Royal Historical Society p. 42; V. H. Galbraith, Domesday Book (1974). On the continental codes, see A. Watson, The Civil Law Tradition (1981); P. Goodrich, "Traditions of Interpretation and the Status of the Legal Text" (1986) 6 Legal Studies p. 53, and Reading the Law (1986) chaps. 2, 4.

H. de Bracton, De Legibus Vol. ii, pp. 124-5. For linguistic details, see D. Mellinkoff, The Language of the Law (1963).

M. Chibnall, "Charter and Chronicle: The Use of Archive Sources by Norman Historians" in Brooke and Luscombe (eds.), op. cit., n. 22; M. T. Clanchy, op. cit., n. 14, chap. 5; W. Ong, op. cit., n. 13, chap. 4.

T. F. Plucknett, A Concise History of the Common Law (1956); J. P. Dawson, The Oracles of the Law (1968); H. J. Berman, op. cit., n. 22, pp. 153-6.

Clanchy, op. cit., n. 14, pp. 26-7, 123-4.

See D. W. Sutherland, Quo Warranto Proceedings in the Reign of Edward I (1963).

C. S. Lewis, in 3 Oxford History of English Literature (1954) p. 60; W. Ong, Ramus, Method and the Decay of Dialogue (1958) chaps. 6-7; E. R. Curtius, op. cit., n. 2, chap. 4; P. Goodrich, Reading the Law (1986) chap. 6.

See G. Lapsley, “Buzones” (1932) English Historical Rev. p. 179.

See Plucknett, op. cit., n. 31, pp. 719ff; F. Wormald and C. Wright (eds.), The English Library before 1700 (1958); J. H. Alexander and M. T. Gibson (eds.), Medieval Learning and Literature (1976); M. T. Clanchy, op. cit., n. 14, pp. $125 \mathrm{ff}$.

Alcuin, cited in E. R. Curtius, op. cit., n. 2, p. 314.

Generally see W. Ullman, op. cit., n. 27, chaps. 6-7, and The Medieval Idea of Law (1946);

H. Kantorowicz, Studies in the Glossators of Roman Law (1938).

Coke, Reports (1826) Vol. 2, pp. xiv-xviii.

See particularly, G. E. Woodbine, "The Language of English Law" (1943) 18 Speculum pp. 395-436; D. Mellinkoff, The Language of Law (1963). More generally, see H. LevyUllman, The English Legal Tradition (1935); T. F. Plucknett, Early English Legal Literature (1958); F. Pollock and F. W. Maitland, The History of English Law before the Time of Edward I (1898); Blackstone, Commentaries on the Laws of England (1916 ed.).

See J. P. Dawson, op. cit., n. 31; H. J. Berman, op. cit., n. 23, pp. 434-461.

See particularly, R. W. Southern, "Master Vacarius and the Beginning of an English Academic Tradition" in J. L. Alexander and M. T. Gibson (eds.), Medieval Learning and Literature (1976) pp. 257-87; P. Stein, "Vacarius and the Civil Law" in Brooke and Luscombe (eds.), op. cit., n. 22, pp. 119-37; E. Rathbone, "Roman Law in the AngloNorman Realm" in (1967) 11 Studia Gratiana p. 256.

J. E. A. Jolliffe, The Constitutional History of Medieval England (1961) p. 206.

G. D. G. Hall (ed.), Treatise on the Laws and Customs of the Realm of England Commonly called Glanvill (1965) pp. 1ff, 167ff.

The exemplary works are by the classicist and historian of civil law, P. Legendre, L'Amour du Censeur, Essai sur l'Ordre Dogmatique (1974) chaps. 2-3, and Jouir de Pouvoir, Traité de la Bureaucratie Patriote (1976) chaps. 2-4. Commenting in the latter text on the 'delirium of the institution": "There is thereby established a Text, that is to say a species of linguistic capital, subject in consequence to norms of conservation and of uniformly identifiable procedures of reproduction. Without these we would be neither astonished by the durability of the text, nor by its logic which signifies in no uncertain manner an untouchable and incontestable phenomenon. As with language, so with the law and the jurists, that race of interpreters who are nothing more than a sub-species of linguist." (pp. 62ff) See also Pattison, op. cit., n. 3, chap. 3; A. Glucksmann, The Master Thinkers (1980) chap. 2; M. Richter, op. cit., n. 25.

Suetonius, Octavius (Loeb Classical Library ed. 1951) p. 88.

E. Auerbach, op. cit., n. 14, pp. 251-74, 371ff; E. R Curtius, op. cit., n. 2, pp. 25ff, 351-6; W. Ong, op. cit., n. 13, pp. 112-6.

M. Bakhtin, The Dialogic Imagination (1982) pp. 278ff. Discussed in P. Goodrich, Legal Discourse (1987) pp. 151-7. W. Ong, op. cit., n. 13, pp. 113-4: "[A] first language to none of its users, pronounced across Europe in often mutually unintelligible ways but always written 
the same way, learned Latin was a striking exemplification of the power of writing for isolating discourse...."

For the periodisation of the different languages of the law, see G. E. Woodbine, op. cit., n. 40, pp. 396ff; D. Mellinkoff, op. cit., n. 40,

See the relevant entries in the Oxford English Dictionary.

77 Eng. Rep. 1123 , K.B. 1614, p. 1128.

Blackstone, 3 Commentaries pp. 320-1.

Epistolae 8.1, 9.34-6.

Cited in E. R. Curtius, op. cit., n. 2, pp. $257 f f$.

Cited in M. Richter, op. cit., n. 25, p. 75.

For further references, see F. H. Bauml, op. cit., n. 14; M. T. Clanchy, op. cit., n. 14; E. R. Curtius, op. cit., n. 2, pp. 350-7, 383-91; B. Bischoff, "The Teaching of Foreign Languages in the Middle Ages" (1961) Speculum pp. 209-24.

See Auerbach, op. cit., n. 14, pp. 203-16; E. R. Curtius, op. cit., n. 2, chap. 8.

F. W. Maitland, "Of the Anglo-French Language in the Early Year Books" in Year Books of Edward II (1903) pp. xxxiii, xxxvi.

On the institutional writers more generally see J. Cairns, "Blackstone, An English Institutist" (1984) 4 Oxford J. Legal Studies p. 318.

Butler (ed.), Coke: Commentary on Littleton (1832) pp. xxxix-lx.

Statute of Pleadings, 1364, 36 Edw. III. Stat. I. c. 15.

Bentham, 3 Works (Bowring ed. 1843) p. 272.

Respectively, II Acts and Ordinances of the Interregnum, 1650, p. 455; 1731, 4 Geo. II. cl. 26; Blackstone commented on the latter in 3 Commentaries p. 323.

G. E. Woodbine, op. cit., n. 40; D. Mellinkoff, op. cit., n. 40, pp. 117-34, 145-70; R. W. Benson, "The End of Legalese" (1984/5) XIII Rev. of Law and Social Change p. 520; J. Boyd White, Heracles' Bow (1985) pp. 62-72.

On the relation between literacy and property ownership, see Bauml, op. cit., n. 14. On the severity of the law and the maxim qui cadit a syllaba cadit a tota causa (he who fails in a syllable fails in his whole cause) see Bacon, 5 Works (Mongatu ed. 1825). For illustration, see for example, Willison v. Crow [82 Eng. Rep., 541-2, 1648]; King v. Wood [82 Eng. Rep. 598, 1649].

For a contemporary argument as to the inevitability of this process, see Stark, "Why Lawyers Write Badly" (1984) Harvard Law Rev. p. 1389.

Elyot, The Boke Named Governour (Everyman ed. 1937). See also Abraham Fraunce, The Lawiers Logike (1588).

\section{Elyot, op. cit., n. 67, p. 65.}

See J. P. Dawson, op. cit., n. 31; R. Shoeck, "Rhetoric and Law in mid-sixteenth Century England" (1953) 50 Studies in Philology pp. 110-27; P. Goodrich, Reading the Law (1986) chap. 6.

F. Hargrave (ed.), A Collection of Tracts (1787) at p. 270.

Bacon, 3 Works, p. 140.

3 Coke's Reports, xi.

Roger North, A Discourse on the Study of the Laws (1824) pp. 11-14.

M. Foucault, The Order of Things (1974) chaps. 2,3,7 is still the best introduction to the issue of representation. On legal semiotics, see B. S. Jackson, Semiotics and Legal Theory (1985).

On which, see M. Bakhtin, op. cit., n. 48, chap. 4.

S. Humphreys, "Social Relations on Stage: Witnesses in Classical Greece" (1985) 1 History and Anthropology p. 313, at p. 350; see also P. Goodrich, Reading the Law, pp. 168-72; D. MacDowell, The Law of Classical Athens (1978) pp. 17ff.

7 See more generally: E. Auerbach, op. cit., n. 14, pp. 240-9; P. Goodrich, Legal Discourse pp. 89-98. On the declaration of laws, see P. Stein, Regulae Iuris (1966) pp. 3-26; F. Schulz, History of Roman Legal Science (1953); W. Kunkel, An Introduction to Roman Constitutional and Legal History (1973).

Pliny, Epistolae, 9.23.2.

Such being of course the peculiar thesis of Habermas, best approached via J. Habermas, 
-"The Public Sphere" (1974) 3 New German Critique pp. 49-56, and Communication and the Evolution of Society (1979) chap. 5.

80 E. Auerbach, op. cit., n. 14, p. 248.

81 Tacitus, Dialogus (Macmillan ed. 1914) p. 103.

82 Id., pp. 108-10: "Thus in addition to the subject-matter which is so far removed from real life, there is the bombastic style in which it is presented. And so it comes that themes like these: 'the reward of the king-killer' . . . or 'the remedy for the plague' or the 'incestuous mother' and all the other topics that are treated everyday in the school but seldom or never in actual practice are set forth in magnificent phraseology...."

83 Id., p. 127.

84 Pliny, Epistolae, 9.2.2f.

85 In Robertson (ed.), Anglo-Saxon Charters (2nd ed. 1956) pp. 44-7.

86 The principle of concession is well discussed in W. Ullman, op. cit, n. 27, pp. 62-7, 200-1.

87 See F. Bauml, op. cit., n. 14, pp. 253-5.

88 E. Auerbach, op. cit., n. 14, pp. 203-16; M. T. Clanchy, op. cit., n. 14, pp. 186-97.

89 See Auerbach, op. cit., n. 14, pp. 250ff; R. W. Southern in Alexander and Gibson (eds.), op. cit., n. 36; F. W. Maitland, "Magistri Vacarii Summa de Matrimonio" (1897) 13 Law Q. Rev. p. 133.

90 Thomas More, Utopia (1516/1901 ed.) p. 203.

91 Cited in M. T. Clanchy, op. cit., n. 14, pp. 146-7. 